\title{
Analysis of Methodologies for Assessment of Urban Drainage Impacts in Lakes and Reservoirs
}

\author{
A.E. Barbosa ${ }^{*}$, J.N. Fernandes and A.R. Vieira
}

National Laboratory for Civil Engineering - LNEC, Av. do Brasil, 101, 1700-066 Lisboa, Portugal

\begin{abstract}
The water quality of rivers, lakes or reservoirs changes in both short and long term. For a given catchment with known pollution sources, different combinations of hydrologic and pollutants discharges scenarios may result in different impacts in the water quality. The objectives of the present work were to analyze the methodologies currently used for assessment of pollution impacts in lakes and reservoirs, and to get an insight on how much research focus on urban drainage as a pollution source. Based on the evaluation of a sample of 17 papers, dated between 2000 and 2012, from different countries it was concluded that monitoring data is the most used method for studies in water quality of lakes and reservoirs. Records from historical databases or from continuous monitoring are used by some authors; but most of the time the research includes a designed monitoring program. It was interesting to realize that the application of three different methodologies - i) simple modeling; ii) simple monitoring and iii) analysis of long term monitoring data - to assess the impacts of road runoff and agriculture discharges in a reservoir in Central Portugal resulted in similar conclusions, emphasizing the importance of long duration monitoring records. Most of the analyzed papers evaluated agriculture pollutants. Nevertheless, it has been proved that road runoff may discharge pollutants in concentrations that exceed the limits for point wastewater discharges; therefore it seems there are improvements that should be made in future studies of pollutant impacts in lakes and reservoirs.
\end{abstract}

Keywords: Lakes, Methodologies, Pollution sources, Portugal, Reservoirs, Urban runoff, Water quality.

\section{INTRODUCTION}

The good status of water masses is an objective in water resources management and is the scope of law requirements. For instance, European directives (e.g. the Water Framework Directive 2000/60/EC, WFD), focused on the condition of water bodies, dictate that evaluations of the water should include quality and ecological elements $[1,2]$. Water quality evaluations are relevant, as well, to have references for standard conditions [e.g. 3].

The water quality of rivers, lakes or reservoirs changes in both short and long term. It can be directly affected by climate related events like droughts, intense rainfalls or floods [4]. In some climates flow discharge is highly variable along the year and water resources show considerable flow and volume variations. The dry season can be critical due to low-flow conditions, high temperatures and a limited dilution capacity [5-7].

In lakes and reservoirs volume shortage may cause a decrease in the water quality and interferences with the water uses. This confined type of fresh water systems allows high dilution of pollutants decreasing their possible impacts and, at the same time, accumulate them at the bottom, which may cause acute impacts under certain circumstances. For a given catchment with known pollution sources, different combinations of hydrologic and pollutants discharges scenarios may

*Address correspondence to this author at the LNEC, Av. do Brasil, 101, 1700-066 Lisboa, Portugal; Tel: +351218443442; Fax: +351218443016;

E-mai: aestela@lnec.pt result in different impacts in the water quality. It is common that the average concentrations of pollutants in the inflow waters are highest than at the lake or reservoir; but it is also observed that the values rise in the lowest parts of the system [e.g. 3].

An important variable affecting physical and chemical processes is the water depth at the lake or reservoir. Thermal stratification is a common phenomenon in lakes with higher water depths. Shallow lakes are usually well mixed by wind; therefore the temperature and oxygen in the water column are homogeneous. However, if summer conditions are of calm weather, the demand for dissolved oxygen may be so high that the bottom sediment surface may become deoxygenated, even in such shallow lakes or reservoirs. [e.g. 12, 16].

Most of the research studies on lakes or reservoirs characterize relevant variables such as the local climate, the surface area of the system and the depth. The residence time is not so often mentioned [e.g. 5, 8]. Other characteristic usually not referred to is the vegetation cover: the USA EPA [9] found a strong association between water quality and the percentage of vegetated buffer existing at the catchment and surrounding the lake or reservoir. Simulation of 5 different future scenarios for phosphorous $(\mathrm{P})$ load reduction at the Black River catchment (Ontario, Canada) revealed that, among all scenarios, the control of sediments using buffer strips and bank erosion controls resulted in one of the best $\mathrm{P}$ load reductions [10].

Comprehensive monitoring, organization of information, data analysis and modelling are actions that allow the identi- 
fication and assessment of impacts in the water quality. There is the need to monitor water systems for extended periods in order to minimize the uncertainty related to temporal variability $[3,11]$. Such actions require a considerable investment of time, and human and material resources. If the water body has historical water-quality data such information is precious for understanding the relationship between water quality and temporal changes in the land use [e.g. 12] or skipping steps in designing a field monitoring plan [e.g. 3, 11].

Statistics and trend analysis as well as relations between concentrations or loads and hydrological variables (e.g. discharge, water temperature, and rainfall) are other methodologies used to assess impacts in water quality [8, 11, 13]. Finally, a huge variety of models exists and they are cited by several authors, from simple export coefficients; to regression models or complex numerical models [7, 10, 14-17].

Among the pollution sources of lakes and reservoirs, agriculture, livestock, and domestic sewage are most often quoted as major problems [7, 10, 13, 18]. Searches made by the authors for water quality models that included pollutants typical of stormwater were unsuccessful.

Therefore, the objectives of the present work were both to analyze the methodologies currently used for assessment of pollution impacts in lakes and reservoirs, and, at the same time, to get an insight on how much research includes urban drainage as a pollution source.

\section{PROCEDURE FOR ANALYSIS OF CURRENT METHODOLOGIES}

There are a few known methodologies for assessment of impacts of pollution sources in water bodies. From land use scoping and identification of point and diffuse pollution sources, to modeling, based on known emission coefficients, to field work and statistical analysis; or a combination of several approaches - the time, human and material resources needed for each of these actions are different and the results are also unlike in their approach to reality and thoroughness. The chosen methodology should be consistent and in accordance with the objective of the study. For instance, simple modeling methods, based on emission coefficients are suitable for land planning purposes, when politicians need to know the impact of land use changes on water quality; but are not suited to know if the water quality complies with law regulations.

It was understood as relevant to start by gaining a good overview of the most used methodologies in this kind of studies, of the main questions addressed and to analyze if the common methodologies are capable of answering to the key issues. The most used methodologies are the following:

- $\quad$ Long term monitoring data (for a selected number of indicative parameters).

- Monitoring in accordance with a design plan, targeting to a specific objective.

- Simple modeling.

- Complex (numerical) modeling.

The procedure adopted was, first of all to gather from the literature a representative sample of recent studies concern- ing assessment of impacts in lakes and reservoirs (section 3). Then this sample of studies was evaluated, in terms of the objective of the work, the pollutants appraised, the consistency of the methodology(ies) used and if it was sufficient to accomplish the objectives. A key issue was, as stated before, to realize how much work concerns specifically urban stormwater impacts, since there is a tradition in evaluation of impacts from agriculture, livestock and sewage discharges, and it seems that urban drainage is seldom addressed to.

In a second step there was a practical application of different methodologies to assess the impacts of road runoff and agriculture discharges in a reservoir in Central Portugal, the S. Domingos (section 4). This is a small reservoir, characterized by data from continuous water quality monitoring from the Portuguese Water Institute, and also simple field monitoring work [12]. The results are discussed herein, in order to understand if different methods may lead to different conclusions.

\section{LITERATURE SURVEY RESULTS}

\subsection{Study Sample}

In order to have a representative and not too extensive sample of studies published in scientific journals, the adopted procedure was: i) to search in scientific data bases using relevant key words; ii) to consider recent studies, published from 2000 up to 2012, and iii) to analyze if the obtained sample of studies had at least 15 elements, concerning both lakes and reservoirs from at minimum, 10 different countries, located at least in 3 distinct continents.

At the end of the search 17 published papers were selected; 14 of them dated from 2008 to 2011; meaning that they are quite recent. From the remaining, 2 were published in 2012 and 1 in 2000 . They were able to fit to all set requirements.

Table 1 presents a summary of the sample of studies that were analyzed in this paper. Seven of them concern to reservoirs and the remaining to lakes; the countries where they are located are: Argentina, Canada, China, Greece, Israel, Nigeria, Pakistan, Poland, Portugal, Russia and the USA, therefore covering different climatic regions and research backgrounds. China, Canada, Portugal and the USA are represented by more than one study.

The following 3 groups of studies have been considered, according to the methodology:

- M1: Studies based on monitoring data, including large database for a long period of time and more restricted data.

- M2: Studies based on a combination of modeling and monitoring data; usually the latter being used for model calibration and validation.

- M3: Studies based on modeling (both simple and complex).

\subsection{Discussion of the Results}

\subsubsection{Overview and Most Used Methodologies}

The sample covered a wide variety of study site characteristics: the water depth varied between $0.5 \mathrm{~m}$ to $150 \mathrm{~m}$, and 
Table 1. Summary of the 17 Studies Used for Analyzing three Methodologies (M1, M2 and M3) for Impacts Assessment in Lakes and Reservoirs

\begin{tabular}{|c|c|c|c|c|}
\hline & Country & $\begin{array}{l}\text { Reservoir (R) } \\
\text { or Lake (L) }\end{array}$ & Targeted Pollutants & Scope and Objectives \\
\hline \multirow{8}{*}{ M1 } & $\begin{array}{l}\text { Argentina } \\
\text { [12] }\end{array}$ & $\mathrm{R}$ & 30 water quality parameters & $\begin{array}{l}\text { To analyze spatial and temporal variations in water quality and identify } \\
\text { contamination patterns. }\end{array}$ \\
\hline & Pakistan [19] & $\mathrm{L}$ & $\begin{array}{l}\text { TSS; turbidity; cond; } \mathrm{Mn} ; \mathrm{Cl} \text {; } \\
\mathrm{NO}_{2}^{-} \text {; Tot col; Faecal col; } \mathrm{DO} \\
\text { and } \mathrm{BOD}_{5}\end{array}$ & $\begin{array}{l}\text { To understand water quality problems and provide information for govern- } \\
\text { ment and local authorities to act upon. }\end{array}$ \\
\hline & USA [3] & $\mathrm{L}$ & $\begin{array}{l}\text { Diss. orthophosphorus }(\mathrm{OP}) \\
\text { Tot-P; diss- } \mathrm{NH}_{3} \text {; TKN; diss. } \\
\mathrm{NO}_{3}+\mathrm{NO}_{2} ; \text { chlorophyl a; TOC; } \\
\mathrm{TN}=\mathrm{TKN}+\left(\mathrm{NO}_{3}+\mathrm{NO}_{2}\right)\end{array}$ & $\begin{array}{l}\text { To identify least-impaired lakes in four lake classifications. Nutrients se- } \\
\text { lected as water quality surrogate to represent anthropogenic risks. }\end{array}$ \\
\hline & Greece [6] & $\mathrm{R}$ & Phytoplankton & $\begin{array}{l}\text { a) To examine the phytoplankton compositional diversity and biovolume } \\
\text { under changing flushing rate. } \\
\text { b) To assess the reservoir's water quality according to both WFD and WHO } \\
\text { guidelines. } \\
\text { Note: first paper on phytoplankton and water quality of this reservoir. }\end{array}$ \\
\hline & Canada [21] & $\mathrm{L}$ & Tot $-\mathrm{Hg}$ & $\begin{array}{c}\text { Use of improved sampling techniques (the ISOMET) to evaluate Tot-Hg } \\
\text { spatial distribution and trends in waters of the Great Lakes and connecting } \\
\text { channels. }\end{array}$ \\
\hline & USA [22] & $\mathrm{L}$ & $\begin{array}{l}\text { Total Hg; methylmercury; } \\
\text { TSS; TOC; Particulate Carbon } \\
\text { (PC) and Loss on Ignition } \\
\text { (LOI) }\end{array}$ & $\begin{array}{l}\text { All } 50 \text { states in the USA have advisories on fish consumption due to Hg } \\
\text { content. Great Lakes are a focal point for } \mathrm{Hg} \text { research because of their rela- } \\
\text { tively small watershed-to-lake ratio: they are suited to assess the relative } \\
\text { importance of direct atmospheric Hg deposition to the lake surface, com- } \\
\text { pared with stream-water Hg input. Lake Champlain has a mountainous wa- } \\
\text { tershed and a much higher watershed-to-lake ratio of } 18 \text { posing an interest- } \\
\text { ing contrast to the Great Lakes for Hg cycling research. }\end{array}$ \\
\hline & Nigeria [8] & $\mathrm{R}$ & $\begin{array}{l}\text { T, Transparency; } \mathrm{pH} \text {, cond; } \\
\text { TDS; DO; } \mathrm{NO}_{3} \text {; P; COD; } \\
\text { Tot-alkalinity; Tot Hard; Ca; } \\
\text { Mg; Si; S; Carbon dioxide. }\end{array}$ & $\begin{array}{l}\text { To assess the water quality of an African tropical reservoir for drinking and } \\
\text { fish production using some selected physic-chemical properties. }\end{array}$ \\
\hline & Portugal [18] & $\mathrm{L}$ & Pesticides and nutrients & Preliminary Assessment of Risks \\
\hline \multirow{3}{*}{ M2 } & Portugal [15] & $\mathrm{R}$ & Nitrogen and phosphorus & $\begin{array}{l}\text { To adequately evaluate nutrient control strategies along the Alqueva water- } \\
\text { shed in Portuguese territory. } \\
\text { Note: The Alqueva dam, constructed in the Portuguese section of the Guadi- } \\
\text { ana River, receives also contributions from Spain. }\end{array}$ \\
\hline & China [7] & $\mathrm{R}$ & Annual $\mathrm{NH}_{4}{ }^{+}-\mathrm{N}$ and $\mathrm{TP}$. & $\begin{array}{l}\text { To evaluate the effect of climate change on future stream flow volume and } \\
\text { non-point source pollutant loads at the inlet of the Shitoukoumen reservoir. }\end{array}$ \\
\hline & Canada [10] & $\mathrm{L}$ & $\begin{array}{l}\text { Phosphorus and suspended } \\
\text { solids }\end{array}$ & $\begin{array}{l}\text { To understand the relative importance of different P sources in catchments } \\
\text { and the relationship between source strength and land use, to describe } \\
\text { source-sink behavior in soils and sediments. } \\
\text { Note: Programme to achieve at least } 40 \% \text { reduction in phosphorus loads to } \\
\text { the lake by } 2045 \text {. }\end{array}$ \\
\hline
\end{tabular}


Table 1. contd....

\begin{tabular}{|c|c|c|c|c|}
\hline & Country & $\begin{array}{l}\text { Reservoir (R) } \\
\text { or Lake (L) }\end{array}$ & Targeted Pollutants & Scope and Objectives \\
\hline \multirow{3}{*}{ M3 } & Israel [16] & $\mathrm{L}$ & $\begin{array}{l}\text { Suspended Particulate Matter } \\
\text { (SPM) }\end{array}$ & $\begin{array}{l}\text { To answer to the question: } \\
\text { - How would water level changes in Lake Kinneret influence the water } \\
\text { quality expressed as changes in concentration of SPM? }\end{array}$ \\
\hline & China [17] & $\mathrm{R}$ & Total-N and Total -P. & $\begin{array}{l}\text { To study pollution loads from Non Point Sources (NPS) in the region, moti- } \\
\text { vated by the presence of several NPS and the national importance of the } \\
\text { reservoir. } \\
\text { Note: in China, excessive nutrient loadings from agriculture watersheds are } \\
\text { considered the main source of NPS pollution. }\end{array}$ \\
\hline & Russia [14] & $\mathrm{L}$ & Phosphorus and phytoplankton & $\begin{array}{l}\text { To investigate the status of Lake Onega with steady state and dynamic mod- } \\
\text { eling approaches, in order to assess the impacts of different loading scenar- } \\
\text { ios of water quality (Water Framework Directive) }\end{array}$ \\
\hline
\end{tabular}

the catchments' area ranged from $0.7 \mathrm{~km}^{2}$ up to $9800 \mathrm{~km}^{2}$. The most frequent focus of water quality studies was phosphorus and nitrogen (6 studies, representing almost $35 \%$ of the study sample). Suspended solids were often combined with the evaluation of a single or a few pollutants, which is also a method to distinguish between particulate and dissolved pollutants. Phytoplankton and other living organisms were the key point in two of the studies $[6,14]$; one of them [14] also looked at phosphorus. Two studies [21, 22] concerned mercury and one study was focused on Polycyclic Aromatic Hydrocarbons, PAH [20]. Almost 24\% of the study sample (4 papers) included a width number of water quality parameters and also biological indicators. Mustapha [8] was focused on more simple water quality parameters (temperature, transparency, $\mathrm{pH}$, conductivity, TDS and dissolved oxygen) but this did not prevent him from developing a good, clear and consistent work.

Concerns with water quality standards for human consumption, or the need to meet legislation or regulations requirements, including the European Water Framework Directive, were often the motivation of the studies. Sometimes, usually when the methodology included modeling, the study tried to evaluate future scenarios in water quality $[7,10]$.

The most used methodology was unquestionably the M1 (monitoring data), with 11 studies, representing $65 \%$ of the sample used in this analysis. Both M2 and M3 were represented with 3 studies.

An appraisal of the consistency expressed in each work, between the study objectives plus the chosen methodologies and then the discussion plus the conclusions, showed weaknesses in 5 of the analyzed papers. Of them, two used methodology M1; one used methodology M2, and other two methodology M3. This evaluation may be considered subjective and reflects the authors' judgment; nevertheless it is interesting to observe that the M3 group, meaning studies based exclusively on modeling, presents the highest level of inconsistency between the objectives and conclusions.

It is known that modeling is a useful tool but the user is restricted to model options and assumptions, and models are often calibrated with a set of data that do not represent universal conditions. It means that a careful use of the methodology and critical discussion of results are crucial to the soundness of model application. Ma et al. [17] used the Ex- port Coefficient Method (ECM) and produced an interesting and very consistent work to predict nutrient inputs to lakes and streams. The authors were careful in referring the problem of using USA export coefficients in China.

\subsubsection{Critical Analysis of the Current Practice}

It was observed that most of the papers described several characteristics of the lakes/reservoirs, but not all included data on the minimum or average water depth; water surface area, water residence time and most relevant climate parameters (precipitation and temperature). It is understandable, that papers such as $[3,21,23]$ that concern a huge system of lakes cannot produce a detailed characterization of each water body, however, it is considered important that key variables should be include in this kind of papers, allowing a better understanding of the results and comparison with other studies.

It seems that monitoring data, concerning both hydrological variables and water quality parameters is still the most used method for studies in water quality. Sometimes data from historical databases or from continuous monitoring (e.g.: flow) are used; several times a designed monitoring program is part of the work. It is known that some sort of studies require huge amounts of data, especially when the water body has seasonal changes in water volume and quality, along the year and between years.

It is not only modeling that has shortcomings; monitoring, sample handling and laboratory analysis so much in focus in water quality assessment require time and resources. The information that may be extracted from a set of data concerning a water mass is strongly dependent on the amount of time dedicated to data analysis and on the technical and scientific knowledge of the experts studying the data.

From the 17 analyzed papers, 7 mentioned the contribution of urban drainage to the lake or reservoir but none characterized this contribution. Diogo et al. [15], Abrantes et al. [18], Ghumman [19] and Shanley and Chalmers [22] mention the presence of "human settlements" or "urban" use at the catchment. Zhang et al. [7], Bilaletdin et al. [14] and Ma et al. [17] refer to the contribution of "domestic wastewater" or "urban sewage". Therefore it may be concluded that urban wastewater is not considered as a relevant target by itself in the evaluation of water quality of lakes and reservoirs, especially when the catchment is large and contains more relevant sources of non point pollution, such as agriculture or livestock. 


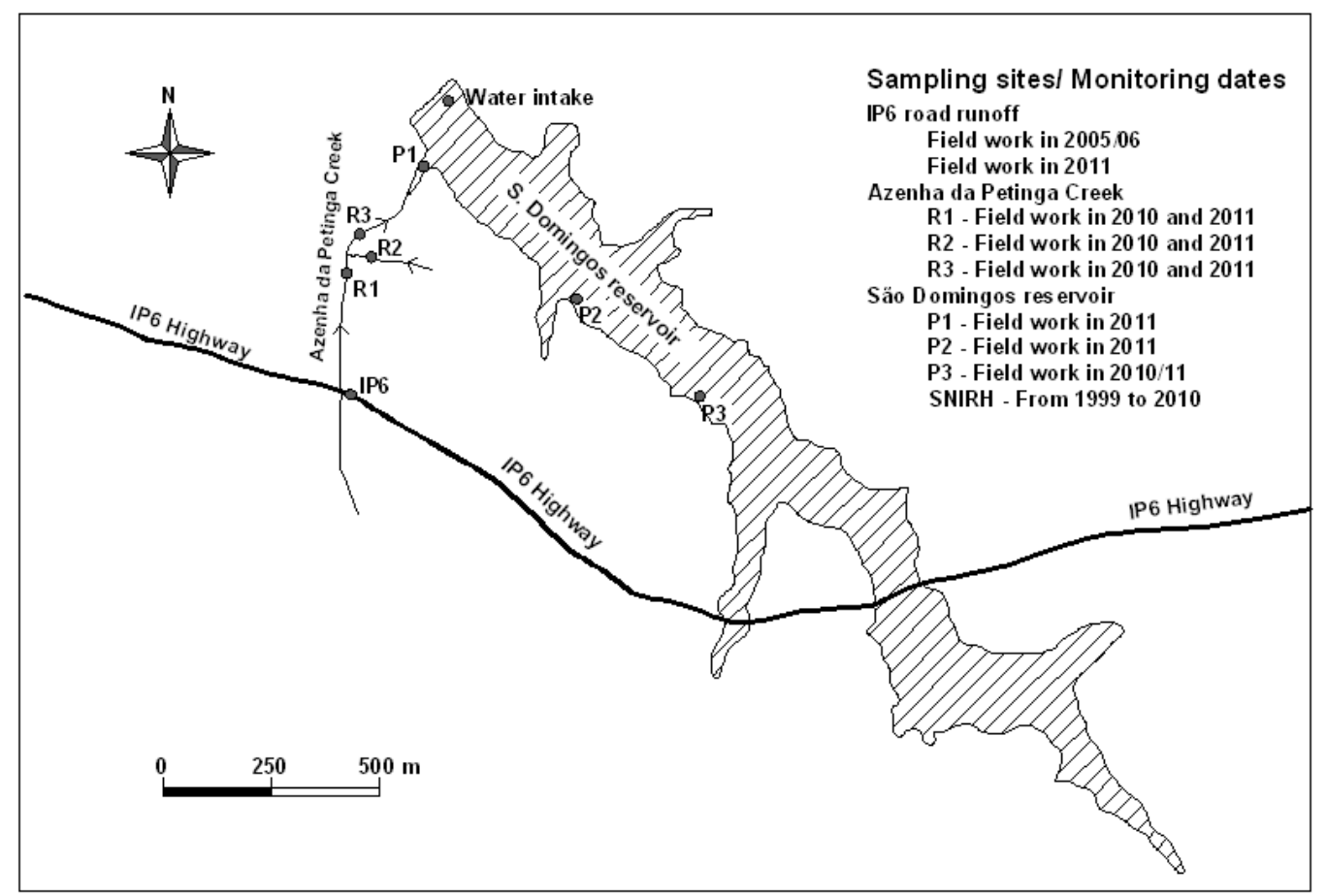

Fig. (1). Schematic representation of the case study and available information.

\section{APPLICATION OF DIFFERENT METHODOLO- GIES TO A CASE STUDY}

\subsection{Case Study Characterization: The S. Domingos Reservoir in PORTUGAL}

The chosen case study is the S. Domingos reservoir, located near Peniche, $100 \mathrm{~km}$ to the North from Lisbon. The watershed has an area of $39.4 \mathrm{~km}^{2}$ and is crossed by a $5.7 \mathrm{~km}$ long section of the IP6 highway (constructed during 20022004). Fig. (1) presents the reservoir, the highway and the Azenha da Petinga creek. Information concerning the water quality monitoring data available, regarding the road runoff; the Azenha da Petinga creek and the reservoir are also depicted in Fig. (1).

A GIS project with the integration of the Corine 2006 land cover was used to characterize the land use [24]. The data was reviewed using orthophotomaps and present uses updated by field survey. Agriculture is the main land use of the reservoir watershed $(66 \%)$, followed by forest $(29 \%)$ and urban areas (4\%). The water bodies represent $1 \%$ of the watershed area.

Data for the period between 1999 and 2009 was used to characterize the precipitation pattern. There is a high interannual variation with a minimum of $401 \mathrm{~mm}$ in 2005 and a maximum of $943 \mathrm{~mm}$ in 2001 . The average annual precipitation is $679 \mathrm{~mm}$. The annual average temperature is around $15^{\circ} \mathrm{C}$ (average monthly temperature from $9{ }^{\circ} \mathrm{C}$ in January to $20^{\circ} \mathrm{C}$ in August).

S. Domingos reservoir has a total storage capacity of $7900 \times 10^{6} \mathrm{~m}^{3}$ whose $7548 \times 10^{6} \mathrm{~m}^{3}$ are effective storage. The minimum operating level is $22 \mathrm{~m}$ and the spillway crest is located at $42.5 \mathrm{~m}$. The reservoir area is 96 ha and the time concentration of the watershed is 2.8 hours. The water from
Table 2. Flow Characteristics of the Azenha da Petinga Creek During the Field Work

\begin{tabular}{|c|c|c|}
\hline Characteristics & $\mathbf{8}^{\text {th }}$ March 2010 & $\mathbf{1 1}^{\text {th }}$ November 2011 \\
\hline \hline Water height $(\mathrm{m})$ & 0.06 & 0.15 \\
\hline Flow area $\left(\mathrm{m}^{2}\right)$ & 0.0252 & 0.1280 \\
\hline Velocity $(\mathrm{m} / \mathrm{s})$ & 0.126 & 0.685 \\
\hline Flow $(1 / \mathrm{s})$ & 3.2 & 87.7 \\
\hline
\end{tabular}

S. Domingos reservoir is used for human consumption. The retention time i.e. the time that the water stays in the reservoir may be an important parameter when dealing with water quality analysis. For Mediterranean countries, with a great seasonality in temperature, precipitation and discharge variations, the retention time has also monthly variation, being much higher in the wet season.

Road runoff treatment systems were constructed to control the pollution from IP6 highway [25]. However, a small extension of the road $(290 \mathrm{~m}$, corresponding to a paved area of $4350 \mathrm{~m}^{2}$ ) drains, without treatment, to the Azenha da Petinga creek that flows into the S. Domingos reservoir (cf. Fig. 1).

Azenha da Petinga creek is an ephemeral water course. The discharge was measured in the two field campaigns in 2010 and 2011, representing two different hydrological conditions, as shown in Table 2.

\subsection{Simple Modeling: Pollutant Loads and Reservoir Volume}

Pollutant loads after dilution in the reservoir water body volume are represented by concentrations, if a simple mass conservation equation is considered. The case is not real, 
Table 3. Pollutant Loads from IP6 road Runoff Discharged to S. Domingos Reservoir

\begin{tabular}{|c|c|c|}
\hline Parameters & $\begin{array}{c}\text { Average Concentration } \\
\text { Discharged (mg/l) }\end{array}$ & $\begin{array}{c}\text { Load } \\
\text { (g/year) }\end{array}$ \\
\hline \hline $\mathrm{Fe}$ & 0.32 & 1390 \\
\hline $\mathrm{Zn}$ & 0.16 & 695 \\
\hline $\mathrm{Cu}$ & 0.02 & 86.9 \\
\hline
\end{tabular}

Table 4. Pollutant Loads from Agriculture, Forest and Urban Land Uses Received at the S. Domingos Reservoir

\begin{tabular}{|c|c|c|}
\hline Modeling Tool & Procedure & Loads \\
\hline SPARROW [28] & Modelled coefficients by land use & $\begin{array}{l}\text { Total-P: } 4.4 \\
\mathrm{Kg} / \text { day }\end{array}$ \\
\hline \multirow{2}{*}{$\begin{array}{c}\text { CE-QUAL-W2 } \\
{[15]}\end{array}$} & \multirow{2}{*}{$\begin{array}{l}\text { The contributions were assumed } \\
\text { to be represented by water quality } \\
\text { monitoring data }\end{array}$} & $\begin{array}{c}\text { Total-P: } 2.4 \\
\text { Kg/day }\end{array}$ \\
\hline & & $\begin{array}{c}\text { Total-N: } \\
25.8 \mathrm{Kg} / \text { day }\end{array}$ \\
\hline \multirow{2}{*}{$\begin{array}{l}\text { Export Coeffi- } \\
\text { cients [29] }\end{array}$} & \multirow{2}{*}{$\begin{array}{l}\text { The emission factors for the } \\
\text { various land uses were obtained } \\
\text { from literature }\end{array}$} & $\begin{array}{l}\text { Total-P: } 31.6 \\
\text { Kg/day }\end{array}$ \\
\hline & & $\begin{array}{c}\text { Total-N: } \\
80.3 \mathrm{Kg} / \text { day }\end{array}$ \\
\hline
\end{tabular}

since the pollutants may be particulate or dissolved and they are usually not conservative, i.e., they may be transformed by physical and chemical processes or assimilated by living organisms. Nevertheless, this methodology can be useful for a preliminary and conservative analysis, and that is the purpose of this section. The land uses considered as relevant pollution sources at the case study catchment are agriculture and the road.

The PREQUALE model was used to estimate the road pollutant loads. It is a multiparametric equation, developed using data from monitoring work at Portuguese roads, that predicts the concentrations of key road runoff pollutants (TSS, COD, Fe, $\mathrm{Zn}$ and $\mathrm{Cu}$ ) [26]. The input variables include the drained area, the impervious percentage, the annual average precipitation and an average precipitation with duration equal to the concentration time of the catchment.

Table 3 presents the results from PREQUALE for $\mathrm{Fe}, \mathrm{Zn}$ and $\mathrm{Cu}$. SST and COD were not considered because road runoff is not their only source at the catchment as they may also be generated by agriculture.

To estimate the total nitrogen and the total phosphorus loads from agriculture, three different emission factors were found in the literature. Table 4 presents results of the application to the study catchment, showing a significant variance of values among the three methods. The results obtained with the emission factors from [15] were chosen for the present study, given the fact that they were between the other two and also the values have been applied by these authors to Portugal.

The $\mathrm{Zn}, \mathrm{Cu}, \mathrm{Fe}$, Total-N and Total-P loads (Tables 3 and 4) from the catchment were diluted in the S. Domingos reservoir water volume, assuming a retention time of 5 months. Note that agriculture fertilizers and pesticides are also a source of $\mathrm{Fe}, \mathrm{Zn}$ and $\mathrm{Cu}$; therefore this approach should un-
Table 5. Estimated Pollutant Concentrations at the s. Domingos Reservoir with Simple Modeling

\begin{tabular}{|c|c|c|}
\hline Pollutants (mg/l) & $\begin{array}{c}\text { Low Storage } \\
\text { Scenario }\end{array}$ & $\begin{array}{c}\text { High Storage } \\
\text { Scenario }\end{array}$ \\
\hline \hline $\mathrm{Fe}$ & $4,08 \mathrm{E}-04$ & $7,33 \mathrm{E}-05$ \\
\hline $\mathrm{Zn}$ & $2,04 \mathrm{E}-04$ & $3,67 \mathrm{E}-05$ \\
\hline $\mathrm{Cu}$ & $2,55 \mathrm{E}-05$ & $4,58 \mathrm{E}-06$ \\
\hline Total-N & 2,72 & 0,49 \\
\hline Total-P & 0,25 & 0,05 \\
\hline
\end{tabular}

derestimate concentrations, by considering the IP6 road runoff as the only source of these pollutants.

The reservoir volume is highly variable in Portugal and other Mediterranean countries; therefore two different scenarios were considered to represent extreme situations, based in data records from the Portuguese national water quality monitoring system [27] $1421 \times 10^{6} \mathrm{~m}^{3}$ (September, 2005) and $7900 \times 10^{6} \mathrm{~m}^{3}$ (total storage capacity). The results, presented in Table 5, should be considered as an approximation of the real concentrations. As expected, the concentrations for the low storage scenario are much higher. This simplified method is based on dilution, but it can provide indicative values if the loads are based in sound emission factors.

\subsection{Simple Field Work}

Simple field work took place at the study site, in two different dates: $8^{\text {th }}$ of March 2010 and $11^{\text {th }}$ of November 2011. The purpose was to characterize the wet season and to assess the contribution from the relevant diffuse sources (agriculture and road runoff) transported by Azenha da Petinga creek to the reservoir.

Samples were collected at the S. Domingos reservoir and the Azenha da Petinga creek (cf. Fig. 1). Samples from S. Domingos were taken from the shore; therefore do not represent a typical average concentration in the water body. They were placed in plastic or glass bottles, refrigerated and transported to laboratories for analysis. The $\mathrm{pH}$, temperature, conductivity and salinity were measured in situ using a Yellow Springs multi-parametric water probe (YSI556MPS).

For both dates the following analyses were conducted at accredited laboratories: TSS, total hardness, $\mathrm{Cl}^{-}, \mathrm{COD}$, Total$\mathrm{P}$ and the heavy metals $\mathrm{Zn}$ and $\mathrm{Cu}$. TOC, $\mathrm{Pb}, \mathrm{Cr}, \mathrm{Cd}$, and $\mathrm{Fe}$ were measured in the 2010 samples. For the samples taken in 2011, nitrates were measured instead of N-Kjeldahl. The results are presented in Table 6; the location of the sampling points at the creek, R1, R2 and R3; and at the reservoir, P1, $\mathrm{P} 2$ and $\mathrm{P} 3$ are indicated in Fig. (1).

The results from November 2011 express the conditions of intense precipitation and flow at the study catchment The presence of very high TSS values, compared to 2010, should express the turbulence and washing out of soil and associated pollutants. On the other hand, the dilution effect was much more significant (flow 27 times higher in 2011, compared to 2010, cf. Table 2) which should be the explanation for the lower concentrations of several pollutants. It is observed that the pollution transported by a local ditch (R2) is considerable indicating agriculture activity ( $\mathrm{N}$ and $\mathrm{P}$ ). It is 
Table 6. Water Quality at the Azenha da Petinga Creek (R1, R2 and R3) and the Reservoir (P1, P2 and P3)

\begin{tabular}{|c|c|c|c|c|c|c|c|c|c|c|}
\hline \multirow{2}{*}{ Parameters } & \multicolumn{4}{|c|}{ March 2010} & \multicolumn{6}{|c|}{ November 2011} \\
\hline & $\mathbf{R} 1$ & $\mathbf{R 2}$ & $\mathbf{R 3}$ & P3 & $\mathbf{R 1}$ & $\mathbf{R 2}$ & $\mathbf{R 3}$ & P1 & $\mathbf{P 2}$ & P3 \\
\hline N-Kjeldahl (mg/l) & 2.3 & 4.5 & 2.9 & 1.5 & NA & NA & NA & NA & NA & NA \\
\hline $\mathrm{NO}_{3}^{-}(\mathrm{mg} / \mathrm{l})$ & NA & NA & NA & NA & 69.4 & 145.9 & 146.8 & 75.5 & 33.6 & 27.8 \\
\hline Total-P (mg/l) & $<0.50$ & $<0.50$ & $<0.50$ & $<0.5$ & 1.10 & 0.70 & 1.00 & 0.4 & 0.2 & 0.2 \\
\hline $\mathrm{Fe}(\mathrm{mg} / \mathrm{l})$ & 7.4 & 1.2 & 3.0 & 0.7 & NA & NA & NA & NA & NA & NA \\
\hline $\mathrm{Zn}(\mu \mathrm{g} / \mathrm{l})$ & $<81.0$ & ND & $<81.0$ & ND & ND & 220.0 & 224.0 & $<108$ & ND & ND \\
\hline $\mathrm{Cu}(\mu \mathrm{g} / \mathrm{l})$ & $<15.0$ & $<15.0$ & $<15.0$ & ND & 37.6 & 48.8 & 45.4 & 10.9 & ND & ND \\
\hline
\end{tabular}

Detection Limits for March 2010: $\mathrm{Zn}=26 \mu \mathrm{g} / \mathrm{l} ; \mathrm{Cu}=5 \mu \mathrm{g} / \mathrm{l}$;

Detection Limits for November 2011: $\mathrm{Zn}=35 \mu \mathrm{g} / \mathrm{l} ; \mathrm{Cu}=3.06 \mu \mathrm{g} / 1$.

ND: non detected.

NA: not analysed

Table 7. Annual Average (ave) and Standard Deviation (sd) of the Concentrations of the Selected Parameters, Annual Precipitation and Annual Storage Volume in S. Domingos Reservoir [27]

\begin{tabular}{|c|c|c|c|c|c|c|c|c|c|c|c|c|}
\hline \multirow[t]{2}{*}{ Year } & \multicolumn{2}{|c|}{$\mathrm{NO}_{3}^{-}(\mathrm{mg} / \mathrm{l})$} & \multicolumn{2}{|c|}{$\mathrm{Fe}(\mathrm{mg} / \mathrm{l})$} & \multicolumn{2}{|c|}{$\mathrm{Cu}(\mu \mathrm{g} / \mathrm{l})$} & \multicolumn{2}{|c|}{ Total-N (mg/l) } & \multicolumn{2}{|c|}{ Total-P (mg/l) } & \multirow{2}{*}{$\begin{array}{c}\text { Annual precip. } \\
(\mathbf{m m})\end{array}$} & \multirow{2}{*}{$\begin{array}{c}\text { Annual Storage } \\
\text { Volume }\left(\mathbf{m}^{3}\right)\end{array}$} \\
\hline & ave & sd & ave & sd & ave & sd & ave & sd & ave & sd & & \\
\hline 1999 & 3.53 & 1.82 & NA & NA & 1.8 & 0.75 & NA & NA & 0.06 & 0.02 & 566.1 & $4256 \times 10^{6}$ \\
\hline 2000 & 5.67 & 4.19 & NA & NA & 2.5 & 1.05 & NA & NA & 0.08 & 0.05 & 906.5 & $2568 \times 10^{6}$ \\
\hline 2001 & 12.11 & 7.81 & NA & NA & 2.8 & 1.47 & NA & NA & 0.14 & 0.11 & 943.4 & $6868 \times 10^{6}$ \\
\hline 2002 & 4.46 & 2.65 & 0.056 & 0.03 & 1.8 & 0.45 & 2.29 & 0.7 & 0.07 & 0.04 & 757 & $4745 \times 10^{6}$ \\
\hline 2003 & 8.71 & 5.43 & 0.069 & 0.02 & 4.2 & 2.14 & 3.84 & 1.4 & 0.08 & 0.05 & 600.5 & $6703 \times 10^{6}$ \\
\hline 2004 & 6.21 & 4.07 & 0.09 & 0.01 & 2.7 & 0.82 & 2.62 & 1.3 & 0.05 & 0.02 & 414.2 & $5672 \times 10^{6}$ \\
\hline 2005 & 3.96 & 4.10 & 0.292 & 0.26 & 3 & 2.00 & 1.99 & 0.6 & 0.1 & 0.06 & 400.5 & $2223 \times 10^{6}$ \\
\hline 2006 & 13.66 & 10.0 & 0.371 & 0.45 & 3 & 0.89 & 3.3 & 2.1 & 0.13 & 0.09 & 892.8 & $2725 \times 10^{6}$ \\
\hline 2007 & 12.96 & 4.48 & 0.13 & 0.01 & 4.8 & 2.71 & 3.22 & 1.3 & 0.15 & 0.07 & 699.6 & $5404 \times 10^{6}$ \\
\hline 2008 & 1.78 & 0.78 & 0.129 & 0.04 & 4.5 & 3.56 & 1.85 & 0.3 & 0.12 & 0.04 & 449.4 & $345 \times 10^{6}$ \\
\hline 2009 & 10.48 & 6.62 & NA & NA & 3.7 & 1.80 & 3.1 & 0.9 & 0.1 & 0.02 & 839.6 & $3063 \times 10^{6}$ \\
\hline 2010 & 6.59 & 5.26 & NA & NA & 2.6 & 0.93 & 2.73 & 1.4 & 0.05 & 0.04 & NA & $5886 \times 10^{6}$ \\
\hline ave & 7.51 & - & 0.16 & - & 3.12 & & 2.77 & - & 0.09 & - & 679 & $4464 \times 10^{6}$ \\
\hline
\end{tabular}

NA: not available

visible the increase in Total-P from 2010 to 2011, agreeing with the field observation of augmented agriculture activity near Azenha da Petinga creek.

As expected, concentrations are higher at the creek than at the reservoir. Considering that the three sampling locations at the reservoir represent the confluence of the creek to the reservoir (P1) and locations in line with that, further inside the reservoir (P2 and $\mathrm{P} 3$ ), the dilution effect of the reservoir water mass receiving the loads from the Azenha da Petinga is clear.

It is considered that this data is very useful to understand the hydrological and quality processes at the catchment, but is also limited since represent two specific scenarios. Much more data, gathered in different hydrological conditions and considering more pollutants would be necessary to assess the impacts of the different pollution sources in the S.Domingos reservoir.

\subsection{Analysis of Long Term Monitoring Data}

S. Domingos reservoir has historical water quality data from the national monitoring system controlled by the Portuguese Water Institute [27]. The data represents samples at the water reservoir intake, collected at $30-50 \mathrm{~cm}$ below the water surface.

$\mathrm{NO}_{3}{ }^{-}, \mathrm{Fe} ; \mathrm{Cu}$, Total-N and Total-P were selected from the water quality parameters available at SNIRH [27], because of their relevance for the present study. Note that information for $\mathrm{Zn}$ was not available. The data, presented in Table 7, concern the period from 1999 to 2010 on a monthly basis; the annual precipitation and storage volume are also included.

The limit concentrations for water quality proposed by the Portuguese legislation are presented in Table 8. Comparing it with the average values from Table 7 it can be seen that all pollutants show concentrations below the minimum environmental objective. Only $\mathrm{Cu}$ is slightly above the limit for drinking water.

\subsection{Comparison of the Results from Different Methodologies}

In this case study, three methods have been used, separately, to assess the quality at the $\mathrm{S}$. Domingos reservoir, in Portugal; they were: i) simple modeling; ii) simple monitoring and iii) analysis of long term monitoring data. 
Table 8. Limits According to the Portuguese Law

\begin{tabular}{|c|c|c|c|c|c|c|}
\hline Limit & TSS (mg/l) & $\begin{array}{c}\text { COD } \\
(\mathrm{mg} / \mathrm{l})\end{array}$ & Cl (mg/l) & $\mathrm{Cu}(\mu \mathrm{g} / \mathrm{l})$ & $\mathrm{NO}_{3}(\mathrm{mg} / \mathrm{l})$ & $\begin{array}{c}\text { Total-P } \\
(\mathrm{mg} / \mathrm{l})\end{array}$ \\
\hline Minimum environmental objective (Annex XXI) & - & - & 250 & 100 & - & 1 \\
\hline Limit for drinking water (Annex VI) & 0 & - & 25 & 3 & 25 & - \\
\hline
\end{tabular}

The first interesting observation is that the results obtained with the simple modeling approach (use of emission factors) for Total-N and Total-P match with the average concentrations from 12 years monitoring data (Table 5 and Table 7). Note that $\mathrm{Fe}$ and $\mathrm{Cu}$ loads (Table 3 ) were estimated only based on the road emissions and there are other sources of these pollutants at the catchment, such as agriculture.

It seems that a general understanding of a reservoir or lake water quality may be achieved with simple modeling but these results must be validated with long term monitoring data, otherwise there is no possibility of knowing how the emission factors are suited to the catchment.

The availability of 12 years of historic water quality data for S. Domingos reservoir was therefore very relevant; in fact only long duration data may provide comprehensive understanding of the processes [e.g. 3, 12]. Noteworthy is that this national database provides information for several water quality parameters; some of them are measured several times a month, others once or twice a year. This information, if correctly used, may be very useful in water quality assessment and maybe Portugal and other countries with similar national database could place more value to it.

The simple monitoring is useful to understand local processes of pollutants transportation and dilution, but not sufficient to draw major conclusions. In this particular case, the data do not characterize average concentrations at the reservoir; the samples were taken from the shore. This is another relevant issue in monitoring: there are significant costs and to use boats to sample at different locations and depths may increase the budget. Options must be made concerning human resources, cost of analysis (number of samples and of locations; number of parameters to be analyzed). Another relevant topic in water quality monitoring is the analytical limitations. For instance, $\mathrm{Cu}$ concentration estimated for the high storage scenario (Table 5) was of $0.00458 \mu \mathrm{g} / \mathrm{l}$; this value is a simulated concentration, much lower than the common detection and quantification limits of the analytical techniques, somehow matching to the "non detected" or "below the quantification limit" obtained with the simple monitoring (Table 6). For this case, the limit of detection for $\mathrm{Cu}$ was of $0.005 \mathrm{mg} / 1$.

Comparison of simple monitoring results with the results from the other two methods indicates that concentrations rise in the lowest parts of the system. It is also obvious the high dilution effect of the reservoir, comparing the results for the samples P1, P2 and P3 (Table 6).

\section{CONCLUSIONS}

The objectives of the present work were to gather an insight into the methodologies currently used for assessment of pollution impacts in lakes and reservoirs, and, also to assess if research is including urban drainage as a pollution source.

Based on a sample of 17 papers, dated between 2000 and 2012 , from different countries it was concluded that monitoring data, concerning both hydrological variables and water quality parameters is the most used method for studies in water quality. It is known that modeling is a useful tool but the user is restricted to model options and assumptions, and models are often calibrated with a set of data that do not represent universal conditions. It means that a careful use of the methodology and critical discussion of results are crucial to the soundness of model application.

Records from historical databases or from continuous monitoring are used by some authors; but most of the time the research includes a designed monitoring program. It was interesting to realize that the application of three different methodologies, i) simple modeling; ii) simple monitoring and iii) analysis of long term monitoring data to assess the water quality of a reservoir in Portugal resulted in similar conclusions, emphasizing the importance of long duration monitoring records.

It is very important to acknowledge that sound monitoring studies require huge amount of data, especially when the water body has seasonal changes in water volume and quality, along the year and between years. Therefore, simple monitoring produces valuable data but with a limitation, because it respects to a specific pollutants' discharge and hydrological scenario.

In the case study, the flow variability at Azenha da Petinga creek in two monitoring dates was of a factor of 27. This creek, like many streams and rivers in Mediterranean countries, does not have flow at all during the dry season; this variability makes it very vulnerable to pollution, and at the same time may hide the presence of pollutants. It is considered that intensive sampling, even if conducted during one whole calendar year, may still represent few information on lake/reservoir conditions because these systems can be susceptible to changes in response to biological and physical alterations even if the nutrient input is relatively stable [3].

A key issue of this work was to realize how much work concerns specifically urban stormwater impacts; it was observed that seldom urban stormwater or road runoff are evaluated as a pollution source that contribute to lake or reservoir water impairment $[$ e.g. 12, 17]. Some papers $[15,18$, $19,22]$ mention the presence of "human settlements" or "urban" use at the catchment; others [7, 14, 17] refer to the contribution of "domestic wastewater" or "urban sewage", but these sources of pollution are not characterized. Most of the work evaluated agriculture pollutants $[$ e.g. 3, 7, 11, 17, 18]. Nevertheless, it has been proved that road runoff may discharge pollutants in concentrations that exceed the limits for point wastewater discharges [26]. 
It seems that there are improvements that should be made in future studies, placing more focus on urban drainage impacts in lakes and reservoirs. Other necessary developments are a better characterization of the river or lake system; for instance, it was observed that several papers did not included data on the minimum or average water depth; water surface area, water residence time and most relevant climate parameters (precipitation and temperature).

\section{CONFLICT OF INTEREST}

The authors confirm that this article content has no conflicts of interest.

\section{ACKNOWLEDGEMENTS}

Monitoring work conducted in March 2010 was supported by the Portuguese Foundation for Science and Technology, Project PTDC/AMB/64953/2006. The authors are grateful to Senior Research Officer José Menaia and Assistant Technician Vitor Napier, from LNEC, for support with sample analysis in 2011.

\section{REFERENCES}

[1] Furhacker M. The Water Framework directive -can we reach the target? Water Sci Technol 2008; 57 (1): 9-17.

[2] Hering D, Borja A, Carsten J, et al. The european water framework directive at the age of 10: A critical review of the achievements with recommendations for the future. Sci Total Environ 2010; 408: 4007-19.

[3] Justus. B. Water quality of least-impaired lakes in eastern and southern Arkansas. Environ Monit 2010; 168(1-4): 363-83.

[4] Song MW, Huang LF, Zhang H, Xie KZ, Wang XH, He GX. Water quality of the Pearl river. the Beijiang. Southern China: implications from multivariate statistical analyses. Environ Monit Assess 2011; 172: 589-603.

[5] Goldyn R, Dondajewska R, Szelag-Wasielewska E, Szyper H. An Appraisal of changes in seasonal water quality during passage through a shallow reservoir in Western Poland. Environ Monit Assess 2009; 151: 181-8

[6] Katsiapi M, Maoustaka-Goouni M, Michaloudi E, Kormas KA. Phytoplankton and water quality in a Mediterranean drinking-water reservoir (Marathonas Reservoir. Greece). Environ Monit Assess 2011; 181: 563-75.

[7] Zhang L, Wenxi L, Yonglei A, Li D, Gong L. Response of nonpoint source pollutant loads to climate change in the Shitoukoumen reservoir catchment. Environ Monit Assess 2012; 184: 581-94.

[8] Mustapha MK. Assessment of the water quality of Oyun Reservoir. Offa. Nigeria. using selected physico-chemical parameters. Turk J Fish Aquat Sci 2008; 8: 309-19.

[9] USA EPA. Best Practices for identifying reference condition in mid-atlantic streams. Office of Environmental Information. Washington DC 20460. EPA-260-F-06-002. August 2006; p. 8. Available from: http://nepis.epa.gov/. consulted 2012.

[10] Whitehead PG, Jin L, Baulch HM, et al. Modelling phosphorus dynamics in multi-branch river systems: a study of the Black River, Lake Simcoe, Ontario: Canada. Sci Total Environ 2011; 412-413: 315-23.

[11] Abaurrea J, Asín J, Cebrián AC, García-Vera MA. Trend analysis of water quality series based on regression models with correlated errors. J Hydrol 2011; 400: 314-52.
[12] Vieira R, Fernandes J, Barbosa AE. Evaluation of the impacts of road runoff in a Mediterranean reservoir in Portugal. Environ Monit Assess 2012.

[13] Cid FD, Antón RI, Pardo R, Veja M, Caviedes-Vidal E. Modelling spatial and temporal variations in the water quality of an artificial water reservoir in the semiarid Midwest of Argentina. Anal Chim Acta 2011; 705: 243-52.

[14] Bilaletdin A, Frisk T, Podsechin V, Kaipainen H, Filatov. A general water protection plan for Lake Onega in Russia. Water Resour Manage 2011; 25: 2919-30.

[15] Diogo PA, Fonseca M, Coelho PS, Mateus NS, Almeida MC, Rodrigues AC. Reservoir phosphorous sources evaluation and water quality modelling in a transboundary watershed. Desalination 2008; 226: 200-14.

[16] Håkanson L, Parparov A, Hambright KD. Modelling the impact of water level fluctuations on water quality (suspended particulate matter) in Lake Kinneret, Israel. Ecol Modell 2000; 128: 101-25.

[17] Ma X, Li Y, Zhang M, Zheng F, Du S. Assessment and analysis of non-point source nitrogen and phosphorus loads in the Three Gorges Reservoir Area of Hubei Province, China. Sci Total Environ 2011; 412-3: 154-61.

[18] Abrantes N, Pereira R, Gonçalves F. Occurence of pesticides in water sediments and fish tissues in lake surrounded by agricultural lands: concerning risks to humans and ecological receptors. Water Air Soil Pollut 2010; 212: 77-88.

[19] Ghumman AR. Assessment of water quality of Rawal Lake by long time monitoring. Environ Monit Assess 2011; 180: 115-26.

[20] Li J, Cheng H, Zhang G, Qi S, Li X. Polycyclic aromatic hydrocarbon $(\mathrm{PAH})$ deposition to and exchange at the air-water interface of Luhu. an urban lake in Guangzhou, China. Environ Pollut 2009; 157: 273-9.

[21] Dove A, Hill B, Klawunn P, Waltho J, Backus S, McCrea RC Spatial distribution and trends of total mercury in waters of the Great Lakes and connecting channels using an improved sampling technique. Environ Pollut 2012; 161: 328-34.

[22] Shanley JB, Chalmers AT. Streamwater fluxes of total mercury and methylmercury into and out of Lake Champlain. Environ Pollut 2012; 161: 311-20.

[23] White MS, Xenopoilos MA, Hogsden K, Metcalfe RA, Dillon PJ. Natural lake level fluctuation and associated concordance with water quality and aquatic communities within small lakes of Laurentian Great Lakes region. Hydrobiologia 2008; 613: 21-31.

[24] Caetano M, Nunes V, Nunes A. Corine land cover 2006 for continental Portugal. Portuguese Environment Agency 2009.

[25] COBA. Consultores de Engenharia e Ambiente. IP6 - Peniche/IC1 (Node with Caldas da Rainha variante). Environmental Impact Study (in Portuguese). Volume 01 - Final report; Volume 06 . Monitoring Programmes 2001.

[26] Barbosa AE, Telhado A, Caliço J, et al. Diretrizes para a Gestão Integrada das Escorrências de Estradas em Portugal. In: Barbosa AE, Ed. UK: Europress 2011; p. 84.

[27] SNIRH. National System of Water Resources Information (2010). Available at: http://snirh.pt/ (Accessed between February 2010 and December 2011).

[28] Alexander RB, Smith RA, Schwarz E. Use of a Spatially referenced watershed model to estimate diffuse phosphorus sources in surface waters of the United States. Proceedings of the $6^{\text {th }}$ International Conference on Diffuse Pollution 2002; pp 209-16.

[29] USA EPA. Handbook for Developing Watershed Plans to Restore and Protect Our Waters. chapter 8: Estimate Pollutant Loads. Office of Environmental Information. Washington DC 20460. EPA841-B-08-002. March 2008; p. 38; Available from: http://www.epa.gov/owow/nps/watershed_handbook. Consulted 2012. 